\title{
Editorial
}

\section{Prepararse para envejecer o cómo hacerlo bien sin dejarse la vida}

La gran aspiración de los habitantes más jóvenes de esta sociedad del bienestar, pero también de la locura, del ritmo frenético, del "para ayer", del "no puede esperar", del sentimiento de insustituibilidad, del compromiso con las mil causas, de la inercia, de la escasa conversación pausada, del "no tengo tiempo ahora”, del "¡horror!... jotro mes que ha pasado!”, insisto, de la locura, es envejecer y además hacerlo de forma saludable, pero me permitirán preguntar: ¿`ómo?

No dudo del valor de esa preparación, no reservo ni un ápice de energías en reconocer su necesidad y predicar con vehemencia en el foro que lo merezca, que hemos de prepararnos para acometer esa etapa de la vida en las mejores condiciones, pero, permítanme ahora un momento de flaqueza.

En su tránsito poco ruidoso desde la juventud a la adultez, alguien muy querido está postrado y con un jaque a su vida o, confiemos, a su vida de antes. Por el clima de confianza que me brindan, amigos y fieles lectores a esta columna gerontológica, sólo aspirante a curiosa, hoy, este idealista triste, se pregunta realmente cómo hacerlo, cómo hacerlo bien, gobernados por esa locura de vida.

¿Cómo detener unos minutos esa tormenta violenta de amaneceres y anocheceres para permitir escuchar el mensaje y cumplir lo que bien aconsejamos a los otros? ¿Cómo hacerlo sabiamente, antes de que se presente una falla anticipada en la salud, cerrando todos los plazos, o con la suficiente antelación para que sirva de algo? ¿Cómo trasladar esa retahíla evidenciada de beneficios a nuestra vida cotidiana sin esperar a que algo dramático lo impida? ¿Cómo no desoír, cambiar de actitud y obrar en consecuencia, viendo lo que sucede en los cuerpos hermanos? ¿Cómo prepararse para alcanzar la cota del descanso, del ocio, de la realización de todo aquello soñado y pospuesto, sin dejarse la vida en ello? ¿Cómo ser conscientes de la necesidad de soltar amarras antes de que la enfermedad, que calladamente puede ir minándote durante años, haga su aparición y trunque tempranamente una vida o esa aspiración a vida plena reservada para la vejez?

Prepararse entraña dedicación. Entrenarse para un buen envejecer necesita de anticipación y sobre todo de creerse que es una obra que merece la pena, que no se puede entender de otra manera y que exige ponerse a ello en firme mucho antes que lo que ahora, seguro, amigo lector, ha programado en su personal reloj.

Este día de cierre de un nuevo número de Gerokomos está claramente apagado en sus tonalidades por alguien que nos ha enseñado a hacer y a sentir y que ahora se debate por un futuro como ella anhelaba. Ángela, todos estamos ahí, a tu lado, con tu mano entre las nuestras, como siempre, a la espera de que des una vez más muestras de tu valor y valer. Seguimos necesitando de tu ardor, de tu criterio y de tu cariño. Por favor, envejece con todos nosotros. No tengo dudas de que todavía hay muchas cosas buenas por llegar.

A los que todavía no hayan empezado esa preparación, a un servidor sin ir más lejos, háganlo hoy.

J. Javier Soldevilla Agreda Director de Gerokomos 